\title{
Fish ladder of Lajeado Dam: migrations on one-way routes?
}

\author{
Angelo Antônio Agostinho*, Elineide Eugênio Marques**, Carlos Sérgio Agostinho**, \\ Deusimar Augusto de Almeida***, Rafael José de Oliveira** \\ and Jussiclene Rodrigues Bezerra de Melo**
}

Fish ladders are generally conceived to reestablish connectivity among critical habitats for migratory species, thus mitigating the impacts of the blockage of migration routes by dams. If this management tool is to be meaningful for conserving fish species, it must provide a fully permeable connection and assure both upward and downward movements. However, because reservoirs have very different hydrodynamics than the original river, it is expected that, at least in the inner area, they may constitute an additional barrier to this movement, especially for descending fish. Thus, the present study sought to determine if migratory fish and their offspring disperse downstream from the dam after ascending a ladder and spawning in the upper reaches of a basin. To achieve this purpose, we evaluated the limitation imposed by lentic areas to the descent of eggs, larvae and adults of migratory species; we also determined the abundance and composition of larvae present in the plankton near the dam, and compared the intensity of the upward and downward movements of adult fish. Samples of ichthyoplankton were taken upriver, inside the reservoir, in the river downstream from the dam, and in the forebay of the Lajeado Dam on the Tocantins River (Luis Eduardo Magalhães Hydroelectric Plant), from October, 1999 through September, 2004. The densities of fish ascending and descending the ladder were determined experimentally on eight occasions, from June, 2004 to March, 2005. Due to difficulties in identifying the true fish origin (up or down) in the environments connected by the fish passage system, the evaluation of the distribution of migratory fish in reservoirs was based on the landings of the commercial fishery conducted along the Itaipu Reservoir during the four years preceding (2001 through 2003) the construction of the lateral channel (fishpassage mechanism). Fish eggs and larvae drifting down the Tocantins River did not appear in samples taken in the lower half of the reservoir; those found in water flowing through the spillways, turbines or fish ladder of Lajeado Dam belonged essentially to non-migratory clupeids that spawn in the inner part of the reservoir. In addition, results showed that in a reservoir with no fish-passage mechanism, migrants select habitats that still maintain riverine characteristics, in the upper parts of the impounded area. The downward movements are negligible compared to those upward, in the experiments conducted in the fish ladder. It is concluded, therefore, that the Lajeado fish ladder, and possibly those at other dams, is essentially a oneway route that promotes upstream movements of migrants, without the necessary return of adults or their offspring. Thus, the low permeability of the connections provided by these management tools can drastically increase the level of environmental impact that they were actually intended to reduce.

Escadas de peixes são geralmente concebidas para restabelecer a conectividade entre habitats críticos de espécies migradoras, atenuando os impactos da interceptação de rotas de migração por barragens. Para que esse instrumento de manejo tenha significado na conservação das espécies é necessário que a permeabilidade dessa conexão seja ampla e que os movimentos ascendentes e descendentes sejam assegurados. Entretanto, como os reservatórios têm uma hidrodinâmica muito distinta do rio original, postula-se que, pelo menos em sua área mais interna ele possa se constituir em uma barreira adicional a esses movimentos, especialmente os descendentes. Assim, esse trabalho busca avaliar se peixes migradores e sua prole dispersam para os trechos abaixo da barragem após a transporem e desovar nos trechos altos da bacia. Com esse propósito, foi avaliado o grau de restrição oferecido pelas áreas lênticas de reservatórios aos deslocamentos descendentes de ovos, larvas e adultos de espécies migradoras, identificada a abundância e composição das larvas presentes no plâncton das imediações da barragem e comparada a intensidade dos movimentos ascendentes e descendentes de peixes. Foram realizadas amostragens de

\footnotetext{
*Nupelia, Universidade Estadual de Maringá, Av.Colombo, 5790, 87020-900 Maringá, PR, Brazil. agostinhoaa@nupelia.uem.br **Núcleo de Estudos Ambientais (Neamb), Universidade Federal do Tocantins, Campus de Porto Nacional, Rua 3, Quadra 17, Jardim dos Ipês, 77500-000 Porto Nacional, TO, Brazil. emarques@uft.edu.br

***Curso de Pós-Graduação em Ciências do Ambiente, Universidade Federal do Tocantins. Avenida NS 15, ALCNO 14, Bloco 3, Sala 15, 77010.970, Palmas, TO, Brazil.
} 
ictioplâncton a montante, no reservatório e em seu trecho a jusante, bem como nas imediações da barragem de Lajeado (rio Tocantins; UHE Luis Eduardo Magalhães) durante o período de outubro de 1999 a setembro de 2004 e determinado, experimentalmente, em oito ocasiões durante o período de junho de 2004 e março de 2005, a densidade de peixes em movimentos ascendentes e descendentes na escada de peixes desse reservatório. Já a avaliação na distribuição de peixes migradores em reservatórios foi baseada no acompanhamento dos desembarques da pesca comercial praticada ao longo do reservatório de Itaipu durante os quatro anos que precederam a construção do mecanismo de transposição atualmente existente (2001 a 2003). Os resultados obtidos demonstraram que os ovos e larvas de peixes em deriva, pelo rio Tocantins, desaparecem das amostras na metade inferior do reservatório e aqueles encontrados na água vertida ou turbinada pela barragem de Lajeado e na escada de peixes pertencem, essencialmente, a clupeídeos não migradores, com desovas nas áreas internas do reservatório. Revelam ainda que, em reservatório sem mecanismo de transposição, os peixes migradores selecionam habitats que ainda mantém características fluviais, nos segmentos superiores da área represada. Os experimentos realizados na escada revelam que os movimentos descendentes são irrelevantes quando comparados aos ascendentes. Conclui-se, portanto, que a escada de peixes de Lajeado, e possivelmente de várias outras barragens, é essencialmente uma via de mão única que promove subidas massivas de migrantes sem o almejado retorno de adultos ou de sua prole. Assim, a baixa permeabilidade das conexões proporcionadas por esses instrumentos de manejo pode aumentar drasticamente o nível do impacto ambiental para cuja atenuação ele foi concebido.

Key words: Fish passage, Reservoir, Downstream migration, Larvae drift, Rio Tocantins.

\section{Introduction}

The accelerated human alterations of the landscape have disrupted the natural fluxes that formerly occurred within ecosystems, communities and populations. In aquatic environments, dam construction limits the flow of nutrients, organisms, matter, energy and genetic information (Puth \& Wilson, 2001), because of changes in the dynamics of the water and the effects of barriers. Among the biotic vectors capable of promoting these flows, migratory fishes are of great importance. This role of migrant fish was described by Taylor et al. (2006), who reported the consequences of dramatic population reductions of a single fish species, the detritivore Prochilodus mariae, to the functioning of the ecosystem in a South American river, which led to the degradation of the entire river system.

More than $15 \%$ of the neotropical fish fauna is composed of migratory species that have wide home ranges, including spawning, nursery and feeding habitats that are sometimes hundreds of kilometers distant from each other (Carolsfeld et al., 2003). Migratory species, almost all Characiformes and Siluriformes, generally include the largest fishes of a basin, which are desired by fishers because of their market value or their performance for sport fishing (Agostinho et al., 2002). Barriers on rivers mainly impact this group by blocking access to the different habitats needed to complete their life cycle (Agostinho et al., 2005). Impoundments in large- and medium-sized rivers certainly contribute to reducing the abundance or even causing the local disappearance of migratory fish species. A series of reservoirs on a river can exclude long-distance migratory species from the basin, and even lead to complete extinction if these species are endemic to the basin. The disappearance of large migratory fishes from some rivers of the Upper Paraná basin, where 140 dams have already been constructed, is a prime example of this problem (Lowe-McConnell, 1999).
The most common reproductive strategy among neotropical migratory fishes involves upriver movements toward spawning grounds, at the beginning of the rainy season; eggs then drift downriver while they develop and hatch in the turbid waters at the beginning of the flood period (Godoy, 1975; Agostinho et al., 2003). Larvae of migratory species are transported to flooded areas along the riverbanks, where they find favorable conditions for shelter and food (nurseries). Spent adults return to the lower stretches in a movement known as the "rodada" (Resende, 2003). This sequence of events, often interrupted by dams, appears to be essential to the maintenance of viable populations of many species of migratory fishes.

With the aim of partially restoring the corridor permeability for fish, dozens of fish ladders were constructed in Brazilian river basins, mainly in Paraná and Atlantic basins. However, studies of these fish passages are recent, and have concentrated on the effectiveness of the ladders in allowing fish to pass upstream (Godinho et al., 1991; Fernandez et al., 2004; Britto \& Sirol, 2005). Unfortunately, their ultimate efficiency as a conservation tool for fish populations has not been considered in these studies. Therefore, no study has assessed whether the fish reach their spawning area, whether their juveniles are viable or contribute to downstream recruitment, or even whether the spawning individuals return to their original area. Several factors explain this tendency, among them being: (i) common sense indicates that fish accumulated below dams need to reach the upper part of the basin; (ii) fish ladders are constructed with diffuse objectives or under legal constraints; and (iii) studies of these longer-term aspects are more complex and more difficult than those studies of events in the fish passes.

One important aspect to be considered in deciding on the construction of fish passes is the return of migrants and recruitment of juveniles to the downstream segment of the population. For conservation purposes, the products of spawning 
(eggs, larvae, and juveniles) must return to the lower stretches of a river (Agostinho et al., 2004). This matter is just as critical or even more critical than the ascent of fish to the upper stretches, but has been systematically ignored in planning fish passages (Quirós, 1988; Clay, 1995). It is expected that one-way movements without effective return passage may adversely affect all the levels of ecological organization, on both sides of the dam.

In this context, we analyzed the possibility that migrant fish and their offspring disperse downstream from the dam after passing it and spawning in the upper reaches of a basin. We considered that in order to move downstream, the fish must reach the dam and pass it with minimum mortality. We therefore hypothesized that: (i) the lentic water of the reservoir is an important barrier for eggs and larvae drifting toward the dam; (ii) migratory fish will avoid the lacustrine conditions in the inner part of the reservoir, concentrating in the riverine and transition zones and thus limiting their access to the dam; and (iii) downward movements through the fish pass will be reduced when compared to upward movements, and will not include post-spawning adult fish.

\section{Material and Methods}

\section{Study area}

The data used in this paper were obtained in the Lajeado and Itaipu reservoirs. Lajeado Reservoir (Luis Eduardo Magalhães Hydroelectric Plant) is located on the Middle Tocantins River (9'45'26'S, 48 22'17' 'W), and was closed in 2002. The reservoir occupies an area of $630 \mathrm{~km}^{2}$ and is approximately $172 \mathrm{~km}$ long; its mean depth is $8.8 \mathrm{~m}$, reaching 35 $\mathrm{m}$ near the dam. The mean residence time of the water is 24 days; the mean surface velocity is $0.083 \mathrm{~m} . \mathrm{s}^{-1}$.

The ladder constructed at Lajeado Dam is a "weir and orifice" type, $874 \mathrm{~m}$ long and $5 \mathrm{~m}$ wide, with a 5\% slope for a difference in level of $36.8 \mathrm{~m}$. Positioned close to the left bank, bordering the tailrace, the ladder has 92 step-tanks with surface orifices $(0.5 \times 1.0 \mathrm{~m})$ and bottom orifices $(0.8 \times 0.8 \mathrm{~m})$, and five still-water resting pools (first pool: 14.4 x $17.0 \mathrm{~m}$; other pools: 10 x $10 \mathrm{~m}$ ). For more detail see Agostinho et al. (2007b). The discharge was approximately $3.3 \mathrm{~m}^{3} . \mathrm{s}^{-1}$ during the study, with a maximum velocity of $2.3 \mathrm{~m} . \mathrm{s}^{-1}$ in the bottom orifice of the step-tanks.

Itaipu Reservoir on the Paraná River, along the BrazilParaguay border, was closed in 1982 . The reservoir is $150 \mathrm{~km}$ long and covers an area of $1350 \mathrm{~km}^{2}$. Its mean depth is $22 \mathrm{~m}$, and its maximum depth reaches $170 \mathrm{~m}$ near the dam. Mean water residence time is approximately 40 days, and the surface velocity in the central reservoir is about $0.6 \mathrm{~m} . \mathrm{s}^{-1}$ (Agostinho et al., 1994). Although the dam has had a nature-like channel fish pass since 2004, we used the data obtained before its construction.

\section{Sampling and data analysis}

The density of eggs and larvae was estimated from samples taken over a stretch of approximately $250 \mathrm{~km}$ in the Tocantins
River, with conical-cylindrical nets $(0.5 \mathrm{~mm}$ mesh $)$ fitted with a flowmeter and towed at the surface. The sampling was carried out before (October, 1999 through September, 2001) and after the closure of Lajeado Dam (October, 2002 through September, 2004). The sampling involved four stations above the impounded area (the most distant was located at approximately $80 \mathrm{~km}$ ), six stations spaced along the impounded area, and one station immediately below the dam. Additional samples of eggs were taken immediately above the dam (forebay), in the ladder (higher, middle and lower sections), downstream from the ladder, in the tailrace, and in the spillway basin. Due to difficulties in identifying most of the larvae to the species level, we expressed results on the order taxonomic level. This was done for the additional samples, including the samples from the station located above the reservoir and the others near the dam axis before and after the closure (Fig. 1). At each station, samples were taken at 4-hour intervals during a 24-hour period. Samples were fixed in $10 \%$ buffered formalin. For each sample, we calculated the volume of filtered water using the flowmeter records and the mouth area of the net. After the samples were sorted, we counted the eggs and identified the larvae to the order level. The spatial variations in ichthyoplankton density for each period were evaluated based on the volume filtered and the number of eggs and larvae recorded, and expressed as numbers per cubic meter.

Limnological variables were measured at the surface from October, 2002 through September, 2004, in seven stations spaced along the stretch sampled for eggs and larvae. Because of the possibility that changes in water transparency would affect predation of eggs and larvae or sedimentation of the eggs, we only used this variable in this study.

The distribution of migratory fishes along the reservoir was based on data from the fish landings of the commercial fishery conducted in the Itaipu Reservoir, during the years 2001-2003, before the operation of the fish passage (a lateral channel; for details see Makrakis et al., 2007b) started. A similar evaluation could not be made for Lajeado Reservoir or in any other reservoir in the Tocantins basin, because of the difficulty in distinguishing the fish that had ascended the ladder from those coming from points upstream. Itaipu Reservoir was divided into 12 fishing areas (main landing points), which were grouped, based on sedimentation rates (Pagioro \& Thomaz, 2002), into three zones (riverine, transition and lacustrine; Okada et al., 2005). Classification of migratory and non-migratory fishes was based on Agostinho et al. (2004).

The proportion of upward to downward fish movements was evaluated for the fish ladder at Lajeado Dam, from April to July of 2004 and December, 2004 to March, 2005. For this purpose, the ladder was drained, the fish were removed, and a mechanical barrier consisting of a steel screen $(5 \times 2 \mathrm{~m})$ with mesh size of $3 \mathrm{~cm}$ between adjacent knots, was installed in its middle section. The operational discharge was resumed, and after 72 hours, the downstream and upstream entrances were blocked with similar screens. All fish removed below and above the barrier were identified, measured and counted, and 
their stage of maturation was determined based on Vazzoler (1996). The reproductive strategies were assigned according to the literature (Vazzoler, 1996; Carolsfeld et al., 2003 and chapters and references therein; Agostinho et al., 2004). This operation was carried out on eleven occasions during the eight months of the study. The results were expressed in number of individuals per $100 \mathrm{~m}^{2}$. The proportion in the species densities moving upward: downward was analyzed.

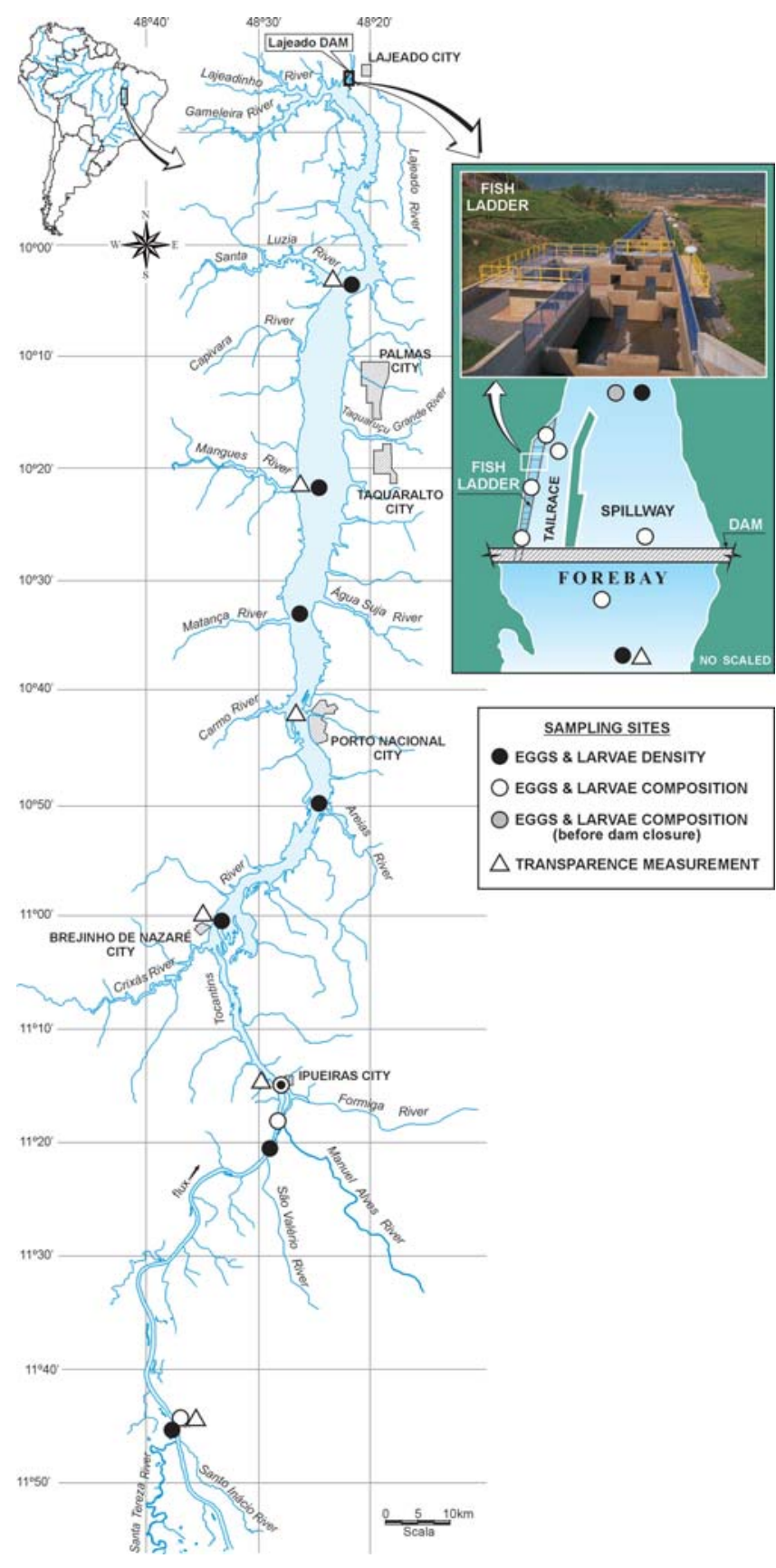

Fig. 1. Sampling sites in the Tocantins River and Lajeado Reservoir (detail: area close to the dam and the fish ladder).

\section{Results}

\section{Distribution and density of the ichthyoplankton and water transparency}

The distribution and abundance of fish eggs and larvae obtained in the main channel of the Tocantins River, during a period of two years before and two years after the formation of Lajeado Reservoir, revealed marked differences. After the impoundment was completed, the densities of both eggs and larvae decreased in the entire stretch evaluated. However, the most important change was observed in the ichthyoplankton densities in the stations in the impounded portion, with a drastic reduction in the upper stretch of the reservoir and virtual disappearance from the inner part (Fig. 2).

Evaluation of the limnological characteristics along the sampled stretch allowed us to demonstrate that the changes in the transport-sedimentation process led to a sharp increase in water transparency, especially in the lower half of the res-
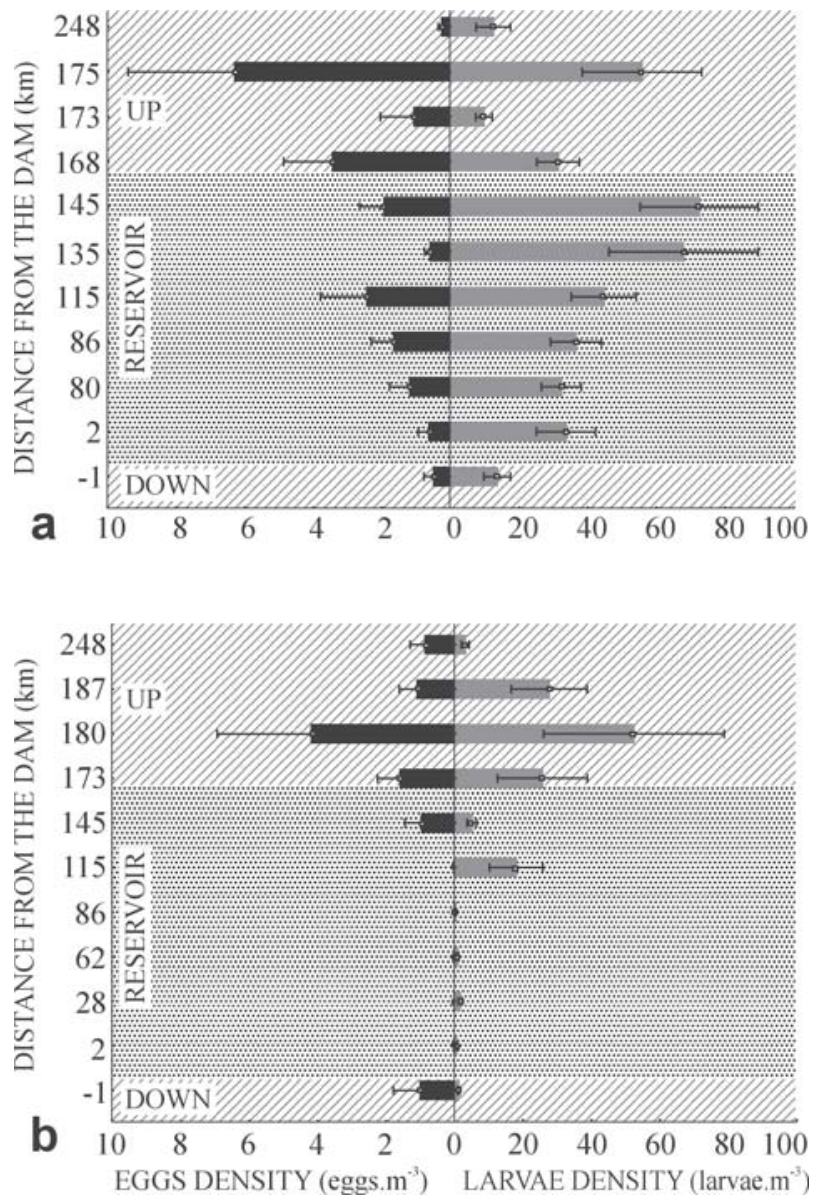

Fig. 2. Spatial variations in the density ( \pm standard deviation - SD) of planktonic fish eggs and larvae in the Middle Tocantins River, before (October, 1999 - September, 2001 - a) and after (October, 2002 - September, 2004 - b) the formation of Lajeado Reservoir (UHE Luís Eduardo Magalhães). 
ervoir (Fig. 3). These changes may have implications for the sedimentation of eggs and for visual predation on the fish eggs and larvae.

The composition of larvae obtained at different points near the dam, including the forebay, tailrace, spillway basin, and the fish ladder (top, middle and bottom), revealed a strong predominance of non-migratory fishes, especially members of the order Clupeiformes $(>80 \%)$. However, larvae of Characiformes and Siluriformes dominated the samples obtained above the reservoir during the same period ( $>95 \%$ of the total) and in the same region before the dam closure $(80 \%)$, Fig. 4 .

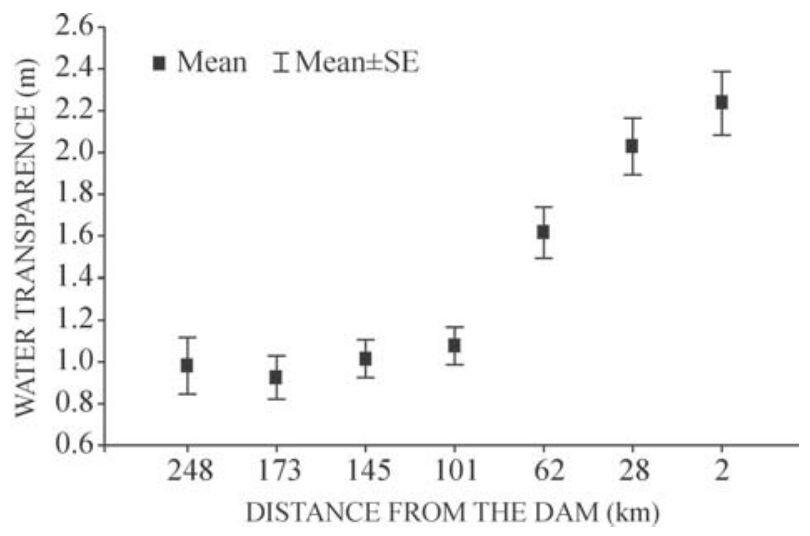

Fig. 3. Mean values of water transparency (Secchi disc, m) upstream from (248 and $173 \mathrm{~km}$ ) and within Lajeado Reservoir, from October, 2003 through September, 2004.

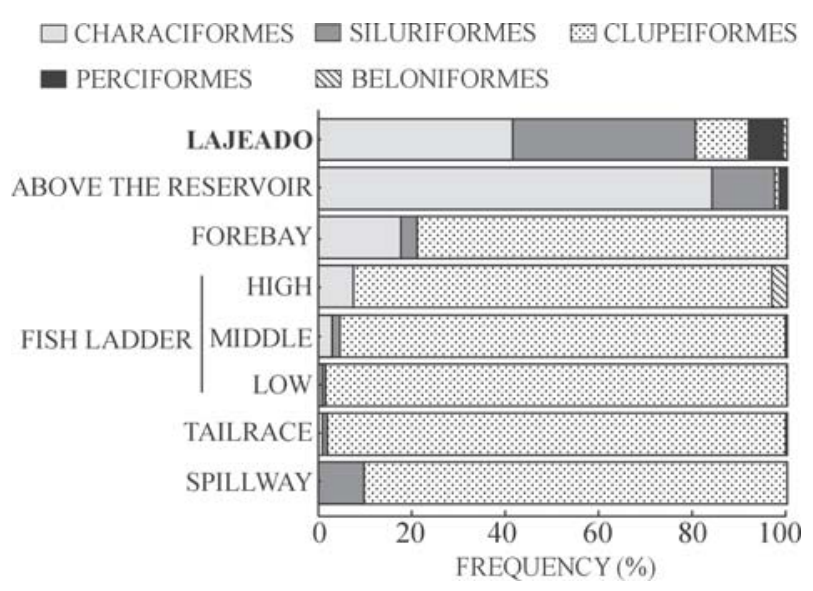

Fig. 4. Proportions of the different orders of fish in the larval samples taken near the Lajeado Dam, before (bold font) and after (regular font) dam closure and above the reservoir after its formation.

\section{Longitudinal gradients in the abundance of fishes in the Itaipu Reservoir fishery}

The spatial gradients in the catches of the ten principal species in the artisanal (commercial) fishery in Itaipu Reservoir, during the period 2001 through 2003 (Fig. 5), revealed that the migratory species, with the exception of Pimelodus maculatus, characteristically occupied the upper half of this reservoir, where the conditions gradually change from riverine to lacustrine. The sedentary species (Plagioscion squamosissimus, Hypophthalmus edentatus, Hoplias malabaricus, Hypostomus ternetzi and Iheringichthys labrosus) concentrate in the inner areas of the reservoir.

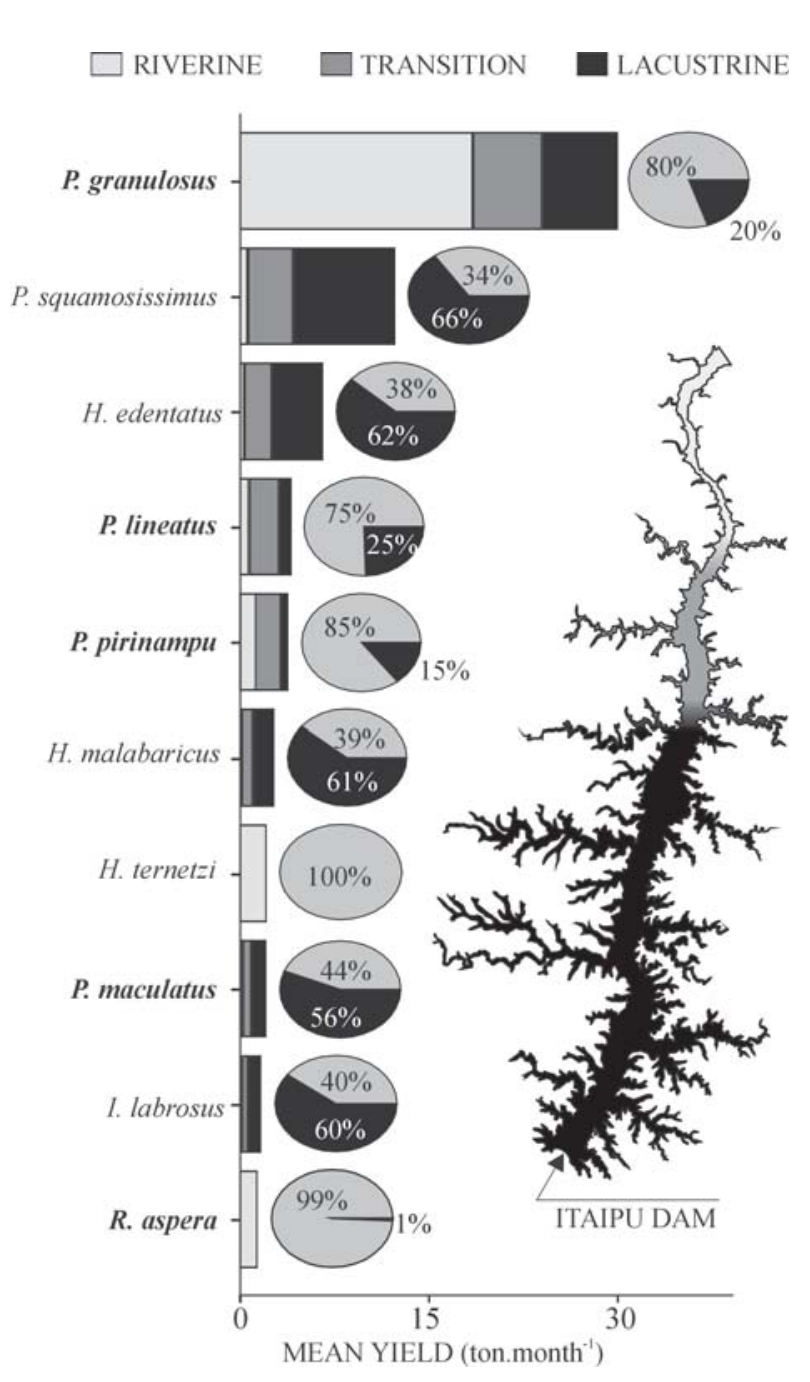

Fig. 5. Yield proportions of migratory (boldface) and nonmigratory species in the commercial fishery conducted in the different zones of Itaipu Reservoir, during the years 2001 through 2003 (the gray tone in the pie charts refers to riverine plus transition zone). 
Table 1. Density (mean number of individuals per $100 \mathrm{~m}^{2} ; \mathrm{se}=$ standard error), occurrence $(\mathrm{Oc}=$ number of times a species was collected in 8 sampling dates) and proportions among the individuals in upward and downward movements in the Lajeado fish ladder, in eight experiments, carried out during the period from April, 2004 through March, 2005.

\begin{tabular}{|c|c|c|c|c|c|c|c|}
\hline \multirow{3}{*}{ Species } & \multicolumn{3}{|c|}{ Upward } & \multicolumn{3}{|c|}{ Downward } & \multirow{3}{*}{$\begin{array}{c}\mathrm{Up} / \\
\text { Down }\end{array}$} \\
\hline & \multirow{2}{*}{$\mathrm{Oc}$} & \multicolumn{2}{|c|}{ Density } & \multirow{2}{*}{ Oc } & \multicolumn{2}{|c|}{ Density } & \\
\hline & & mean & $\mathrm{se}$ & & mean & $\mathrm{se}$ & \\
\hline Long distance migrant & & & & & & & \\
\hline Prochilodus nigricans & 11 & 251.05 & 164.505 & 9 & 0.39 & 0.48 & 643.7 \\
\hline Oxydoras niger & 8 & 82.76 & 30.276 & 4 & 0.34 & 0.68 & 243.4 \\
\hline Hydrolycus armatus & 9 & 9.72 & 2.621 & 5 & 0.10 & 0.21 & 97.2 \\
\hline Brycon gouldingi & 2 & 7.84 & 5.263 & 3 & 0.25 & 0.66 & 31.4 \\
\hline Leporinus friderici & 7 & 6.92 & 2.194 & 2 & 0.05 & 0.15 & 138.4 \\
\hline Brycon falcatus & 4 & 3.95 & 2.565 & 5 & 0.10 & 0.15 & 39.5 \\
\hline Myleus torquatus & 2 & 1.90 & 1.063 & & & & \\
\hline Piaractus brachypomus & 3 & 1.90 & 1.063 & & & & \\
\hline Rhaphiodon vulpinus & 1 & 1.85 & 1.846 & 1 & 0.01 & 0.02 & 185.0 \\
\hline Pseudoplatystoma fasciatum & 4 & 1.65 & 0.980 & 2 & 0.01 & 0.03 & 165.0 \\
\hline Leporinus trifasciatus & 2 & 1.15 & 0.793 & & & & \\
\hline Pimelodus blochii & 1 & 0.95 & 0.812 & 1 & 0.01 & 0.02 & 95.0 \\
\hline Zungaro zungaro & 2 & 0.46 & 0.310 & 3 & 0.03 & 0.06 & 15.3 \\
\hline Semaprochilodus brama & 3 & 0.38 & 0.248 & 3 & 0.03 & 0.07 & 12.7 \\
\hline Tometes sp. & 1 & 0.32 & 0.271 & & & & \\
\hline Sorubim lima & 1 & 0.23 & 0.231 & & & & \\
\hline Subtotal & & 385.97 & 178.024 & & 1.37 & 1.41 & 281.7 \\
\hline \multicolumn{8}{|l|}{ Non-long distance migrant } \\
\hline Myleus setiger & 8 & 60.45 & 22.509 & 9 & 0.19 & 0.059 & 318.2 \\
\hline Serrasalmus rhombeus & 8 & 14.54 & 6.394 & 3 & 0.05 & 0.029 & 290.8 \\
\hline Leporinus affinis & 6 & 8.54 & 2.722 & 4 & 0.09 & 0.063 & 94.9 \\
\hline Leporinus tigrinus & 3 & 3.46 & 2.004 & 1 & 0.03 & 0.032 & 115.3 \\
\hline Brycon sp. A & 2 & 2.54 & 1.874 & 1 & 0.01 & 0.008 & 254.0 \\
\hline Brycon sp. B & 2 & 0.95 & 0.569 & 1 & 0.01 & 0.008 & 95.0 \\
\hline Leporinus sp. B & 1 & 0.95 & 0.812 & 1 & 0.01 & 0.008 & 95.0 \\
\hline Panaque nigrolineatus & 3 & 0.92 & 0.516 & 1 & 0.01 & 0.006 & 92.0 \\
\hline Galeocharax gulo & 2 & 0.63 & 0.354 & 3 & 0.03 & 0.011 & 21.0 \\
\hline Hemiodus unimaculatus & 1 & 0.32 & 0.271 & & & & \\
\hline Leporinus desmotes & 1 & 0.32 & 0.271 & & & & \\
\hline Leporinus sp. C & 1 & 0.32 & 0.271 & & & & \\
\hline Triportheus trifurcatus & 1 & 0.32 & 0.271 & & & & \\
\hline Mylossoma duriventre & 1 & 0.23 & 0.231 & 1 & 0.01 & 0.006 & 23.0 \\
\hline Cichla sp. & & & & 2 & 0.05 & 0.012 & \\
\hline Baryancistrus niveatus & & & & 3 & 0.02 & 0.012 & \\
\hline Leporinus pachycheilus & & & & 1 & 0.02 & 0.015 & \\
\hline Leporellus vittatus & & & & 1 & 0.01 & 0.008 & \\
\hline Myleus sp. A & & & & 1 & 0.01 & 0.008 & \\
\hline Subtotal & & 78.45 & 24.537 & & 0.43 & 0.115 & 182.4 \\
\hline Grand total & & 464.42 & 178.321 & & 1.80 & 0.451 & 258.0 \\
\hline
\end{tabular}

\section{Upward and downward movements in the fish ladder}

The experiments blocking the Lajeado fish ladder performed to evaluate the proportions of upward and downward movements (Table 1) showed that upward movements were 258 times higher than downward movements, during the period. This tendency was more pronounced among migratory species, for which the proportion was 282:1. Upward movements could, however, reach up to 644 times the number of downward movements (Table 1; Prochilodus nigricans). However, the species that showed more intense downward movement also ascended the ladder more often than did other species.

Evaluation of the reproductive stage of the principal species (those with at least one individual in maturation or postspawning) showed that more than $80 \%$ of the females that passed through the ladder were in the resting stage (Table 2; $93 \%$ of those in upward movements). Females in maturation or mature stages or that showed signs of having spawned were recorded in appreciable numbers only among the species with sedentary strategies.

\section{Discussion}

For fish passages constructed at dams to have significant effects on the conservation of migratory species, they must provide good connections to the former habitats by allowing the free transit of individuals both upstream and downstream. At a minimum, they also should allow the offspring, resulting from spawning in the upper stretches, to reach the lower stretches. This aspect has been systemati- 
Table 2. Frequency (\%) of gonadal development stages of females of the principal species moving up and down the Lajeado fish ladder, during the period from June, 2004 through March, 2005. ( $\mathrm{St}=$ Reproductive strategy; LDM = long-distance migratory; $\mathrm{NLDM}=$ non-long-distance migratory; IMT = immature; $\mathrm{REP}=$ resting; $\mathrm{MAT}$ = maturation; $\mathrm{RPD}=$ reproduction; $\mathrm{ESG}=$ spent.

\begin{tabular}{|c|c|c|c|c|c|c|c|c|c|c|c|}
\hline \multirow{2}{*}{ Species } & \multirow{2}{*}{ St } & \multicolumn{5}{|c|}{ Upward } & \multicolumn{5}{|c|}{ Downward } \\
\hline & & IMT & REP & MAT & RPD & $\overline{\mathrm{ESG}}$ & IMT & REP & MAT & RPD & ESG \\
\hline Prochilodus nigricans & LDM & 0.4 & 98.6 & 0.1 & 0.4 & 0.4 & & 96.9 & & 3.1 & \\
\hline Oxydoras niger & LDM & & 94.3 & & 4.5 & 1.1 & 4.8 & 95.2 & & & \\
\hline Hydrolycus armatus & LDM & & 90.9 & & 9.1 & & & 90.0 & & 10.0 & \\
\hline Brycon falcatus & LDM & & 100.0 & & & & & 75.0 & & 25.0 & \\
\hline Brycon gouldingi & LDM & & 100.0 & & & & & 80.0 & & 20.0 & \\
\hline Myleus setiger & NLDM & 1.6 & 77.2 & 1.1 & 17.5 & 2.6 & & & & 90.0 & 10.0 \\
\hline Serrasalmus rhombeus & NLDM & & 46.7 & 3.3 & 43.3 & 6.7 & & 25.0 & & 66.7 & 8.3 \\
\hline Leporinus affinis & NLDM & & 96.0 & & 4.0 & & & 85.7 & & 14.3 & \\
\hline Leporinus tigrinus & NLDM & & 72.7 & & 18.2 & 9.1 & & & & & \\
\hline Total & & 0.5 & 93.1 & 0.3 & 5.0 & 1.0 & 0.7 & 80.4 & 0.0 & 17.4 & 1.4 \\
\hline
\end{tabular}

cally ignored in the planning of these constructions (Quirós, 1988 ) and in analyzing proposals for passage mechanisms as a tool to mitigate impacts (Agostinho et al., 2007b).

The virtual disappearance of eggs and larvae from the plankton samples in the lower parts of the reservoir can be attributed to two different processes, both involving high mortality rates. The first stems from pressure from visual predators, which could be drastically enhanced by the sharp increase in water transparency, as observed in this study. Eggs and larvae, even of large-sized migratory species, can be preyed upon by fish with varied feeding habits such as insectivores and planktophages (Agostinho \& Gomes, 1997; Luz-Agostinho et al., 2006), which are abundant inside reservoirs. Spawning during the rainy periods and in the consequently turbid waters is an adaptation to protect these developmental stages from predation (Agostinho et al., 2002). The second possibility is that eggs and larvae, especially the first, will settle to the bottom in the more lentic conditions of the impounded stretch. Although this possibility has not been evaluated, if it occurs it is probable that the restriction imposed by the low oxygen concentration, or even anoxia, which generally characterizes the bottom of the inner stretches of reservoirs, will cause massive mortalities.

Eggs of migratory fishes are generally slightly denser than the water, and their movement (drift), which is necessary to provide them with oxygen, is promoted by water turbulence (Nakatani et al., 2001). In our study, the evaluations of plankton samples that passed the dam did not reveal the presence of larvae of any migratory groups. Detailed analysis of the planktonic larvae revealed that more than $95 \%$ of the Clupeiformes fish belonged to only the small pelagic species Anchoviella carrikeri (asymptotic length about $4.0 \mathrm{~cm}$ ), which is abundant in the lower half of Lajeado Reservoir. This pelagic-spawning species consumes fish larvae as well as plankton and insects (Pereira et al., in press).

Characiformes and Siluriformes, which include almost all long-distance migratory fishes (Carolsfeld et al., 2003), dominated the samples obtained in the same area before the dam was closed, and after only above the reservoir. Similar results were recorded downstream from Itaipu Reservoir, where 90\% of the larvae present in the samples belonged to only one planktonic species, Hypophthalmus edentatus, which is abundant in the reservoir and spawns pelagically in its centralmost areas (Agostinho et al., 2007b). In fact, the virtual absences of larvae in the inner part of the reservoir and larvae of migratory fish in the samples obtained close to the dam demonstrated that migratory fish spawn in areas above the reservoir and they do not contribute to recruitment of the population segments downstream.

The possibility remains that adults and juveniles return to the stretches downstream. However, the rheophilic behavior of most migratory fish leads them to select the riverine habitats or stretches of reservoir where riverine conditions, although attenuated, are still present (Agostinho et al., 1999). To evaluate this possibility over the length of a reservoir not provided with fish-passage mechanisms, we examined data of the landings of the commercial fishery in Itaipu Reservoir, obtained before the lateral channel was constructed. Migratory species, because of their larger size and commercial value, are preferred by commercial fishermen (Petrere Jr., 1985), and in Itaipu, these species are intensely exploited (Okada et al., 2005). In fact, the results obtained for Itaipu Reservoir revealed that, except for Pimelodus maculatus, all the other, typically migratory species (four of the ten main species landed in the fishery) occurred mainly in the upper stretches of this reservoir. Furthermore, the status of Pimelodus maculatus as a migratory species has been questioned, because its high abundances in reservoir cascades without large tributaries, such as those on the Tietê and Grande rivers (Braga \& Andrade, 2005; Freitas \& Petrere Jr., 2001). Although small shoals may occupy stretches of the reservoir near the dam, it is important to consider the possibility that they do not undergo reproductive migrations. In Lajeado Reservoir, there is a shoal of Prochilodus nigricans that appears to inhabit the forebay permanently, feeding on the periphyton that develops on the walls of the dam (C. S. Agostinho, personal observation). Bonetto \& Castello (1985) noted similar differences within populations of migratory species. 
The importance of the Lajeado fish ladder for returning fish to the downstream stretches may be negligible when compared to the upward movements, especially among migratory species (0.35\%). However, Makrakis et al. (2007a) found different results. They studied the fish ladder constructed at Engenheiro Sergio Motta Dam and noticed that the number of individuals that moved downward represented $72 \%$ of the number that ascended, but $84 \%$ of these were composed of two non-migratory species. Even so, these authors demonstrated that migrants descending represented nearly $18 \%$ of the number ascending the ladder (half belonged to one species). Although those migrants descending the ladder may have come from stretches above the reservoir, it is possible and probable that most of them were recently ascended individuals that accumulated in the forebay and then passed back down the ladder. Unpublished radiotelemetry data showed, for example, that Oxydoras niger that passed the ladder remained in the forebay for a mean of 4.4 days, varying from 1 to 9 days in the 11 individuals monitored.

The construction of fish ladders in Brazilian dams was historically motivated by the success of these facilities in moving salmonids in the northern hemisphere, and the basic differences in the life histories between these fishes and the neotropical migrants were not considered (Agostinho et al., 2004). The upward migrations of salmonids have a strong reproductive motivation, which does not apply to all movements of neotropical migrants (Agostinho et al., 2007c). The downstream movements of salmonids involve juveniles considerably less susceptible to predation and they can be led by physical or behavioral barriers to appropriate passages, but this cannot be done for larvae of neotropical migratory fishes.

Losses of fish passing through dams have not yet been studied in the neotropical ichthyofauna. Nevertheless, it is known that such losses do occur; they vary according to the route taken by the fish, but mortality is generally lower in spillways than in turbines (Clay, 1995). In spillways, mortality rates for fish in the northern hemisphere vary from 0.2 to $99 \%$, depending on the height and design. In turbines, losses can be caused by contact with fixed or moving components, and by rapid changes in pressure, cavitation, shearing effects and turbulence (Ruggles, 1980; Cada et al., 1997; Agostinho et al., 2007a).

Thus, the studies conducted on the Lajeado fish ladder showed that, in addition to the selectivity bottleneck (Agostinho et al., 2007c), there is no indication that migrants return to their points of origin, and the possibility that eggs and larvae can reach the dam and pass through it is remote. Therefore, these movements are essentially one-way. A similar situation must be common in other fish passages. This picture is even gloomier when shoals ascend fish passages to stretches farther upstream where spawning grounds and nurseries are few or nonexistent, but below there are areas where migratory fish can fulfill their life cycle. Probably the fish-passages at Engenheiro Sergio Motta Dam (fish ladder and elevator) on the Paraná River can be included in this case (see the intense upward movement of Rhinelepis aspera in Makrakis et al., 2007b). The stretch below that dam has important tributary rivers that can support intense spawning, and where the floodplain facilitates the initial development of many migratory species. However, in the regions upriver, these habitats are limited and of dubious adequacy (Agostinho et al., 2007a). Mark-recapture studies conducted in this region showed that migratory fish concentrated near the dam before the installation of the passage mechanisms were able to return to the first tributaries downstream and ascend them (Antonio et al., 2007).

Another emblematic case is that of the fish ladders in the Canoas I and Canoas II reservoirs, on the Paranapanema River, which are contiguous and situated between two other reservoirs that do not have fish passages. In the stretch (about 70 $\mathrm{km}$ long) presently occupied by these two reservoirs, there were sustainable populations of large migratory species (i.e., Salminus brasiliensis, Prochilodus lineatus and Pseudoplatystoma corruscans) which apparently used a major tributary on the left bank (Cinzas River), situated just below Canoas I Dam). Tagging studies showed that all marked and recaptured individuals came from these reservoirs, although there was intense fishing activity downstream. Monitoring of the ichthyofauna in the reservoirs and tributary streams did not show the occurrence of larvae or juveniles of migratory species, while the abundance of fish in the ladder declined sharply over the four years of observations (Brito \& Sirol, 2005). Similar situations can occur at other dams where the fish passages are not intensely monitored.

Thus, the results of this study and the sparse information obtained from the literature attest that fish ladders are primarily one-way routes: the lentic environment forms an impassable barrier for eggs and larvae during their dispersal to downstream stretches, and strongly limits the possibility that the migrants which ascend upstream to the spawning grounds above the reservoir, ever return as far downstream as the dam. The reduced incidence of fish moving downwards in the ladder and of larvae of migratory species near the dam perfectly attests to the one-way character of these movements. These findings indicate that a review of the decisionmaking processes regarding the construction of fish passages and a rigorous evaluation of what happens to the fish that pass through the ladders now in operation, are urgent matters. Errors in making decisions to construct fish passages must be recognized, and suspension of their functioning must be considered a possibility. Consideration should be given to improving the downstream movements of eggs, larvae, juveniles, and post-spawning adults. Fish passages must be constructed only after complete knowledge of the effects of the position of the dam in relation to the home ranges of the local species is available. The ascent of fish should be controlled primarily for genetic rather than for demographic reasons. The low permeability of the connections provided by these management tools can drastically increase the environmental impact which they were intended to mitigate. 


\section{Acknowledgments}

We thank our colleagues of the Núcleo de Estudos Ambientais (Neamb), Universidade Federal do Tocantins (UFT), for their assistance in the field and laboratory work, and Edson K. Okada (Nupelia-Universidade Estadual de Maringá) for the Itaipu fishery data. We also thank Investco S.A. for financial support.

\section{Literature Cited}

Agostinho, A. A. \& L. C. Gomes. 1997. Reservatório de Segredo: bases ecológicas para o manejo. Maringá, EDUEM, 387p.

Agostinho, A. A., L. C. Gomes, D. R. Fernandez \& H. I. Suzuki. 2002. Efficiency of fish ladders for neotropical ichthyofauna. River Research and Applications, 18(3): 299-306.

Agostinho, A. A., L. C. Gomes \& F. M. Pelicice. 2007a. Ecologia e Manejo de Recursos Pesqueiros em Reservatórios do Brasil. Maringá, EDUEM, 512 p.

Agostinho, A. A., L. C Gomes, I. S. Suzuki \& H. F. Júlio Jr. 2003. Migratory fishes of the Upper Paraná River Basin, Brazil. Pp. 1998. In: Carolsfeld, J., B. Harvey, C. Ross \& A. Baer (Eds.). Migratory fishes of South America: biology, fisheries and conservation status. World Fisheries Trust, British Columbia, Canada. 380p.

Agostinho, A. A., L. C. Gomes, S. Veríssimo \& E. K. Okada. 2004. Flood regime, dam regulation and fish in the upper Paraná River: effects on assemblage attributes, reproduction and recruitment. Reviews in Fish Biology and Fisheries, 14(1): 11-19.

Agostinho, A. A., H. F. Julio Jr \& M. Petrere Jr. 1994. Itaipu Reservoir (Brasil): impacts of the impoundment on the fish fauna and fisheries. Pp. 419-446. In: Cowx, I. G. (Ed.). Rehabilitation of freshwater fisheries. Oxford, Blackwell Scientific Publications, 486p.

Agostinho, A. A., L. E. Miranda, L. M. Bini, L. C. Gomes, S. M. Thomaz \& H. I. Suzuki. 1999. Patterns of colonization in neotropical reservoirs, and prognoses on aging. Pp. 227-265. In: Tundisi, J. G., M. Straskraba (Eds.). Theoretical reservoir ecology and its applications. São Carlos-SP, Brazil, 370p.

Agostinho, A. A., S. M. Thomaz \& L. C. Gomes. 2005. Conservation of the Biodiversity of Brazil's Inland Waters. Conservation Biology, 19(3): 646-652.

Agostinho, C. S., A. A. Agostinho, F. M. Pelicice, D. A. A. de Almeida \& E. E. Marques. 2007b. Selectivity of fish ladders: a bottleneck in Neotropical fish movement. Neotropical Ichthyology, 5(2): 205-213.

Agostinho, C. S., C. R. Pereira, R. J. Oliveira, I. S. Freitas \& E. E. Marques. 2007c. Movements through a fish ladder: temporal patterns and motivations to move upstream. Neotropical Ichthyology, 5(2): 161-167.

Antonio, R. R., A. A. Agostinho, F. M. Pelecice, D. Bailly, E. K. Okada \& J. H. P. Dias. 2007. Blockage of migration routes by dam construction: can migratory fish find alternative routes? Neotropical Ichthyology, 5(2): 177-184.

Bonetto, A. A. \& H. P. Castello. 1985. Pesca y piscicultura en aguas continentales de America Latina. Washington, D.C.: Secretaria General de la Organización de los Estados Americanos. 118 p.

Braga, F. M. S. \& P. M. Andrade. 2005. Distribuição de peixes na microbacia do Ribeirão Grande, Serra da Mantiqueira Oriental, São Paulo, Brasil. Iheringia Série Zoologia, 95(2): 121-126.
Britto, S. G. C. \& R. N. Sirol. 2005. Transposição de peixes como forma de manejo: as escadas do Complexo Canoas, médio Paranapanema, bacia do Alto Paraná. Pp. 285-304. In: Nogueira, M. G., R. Henry \& A. Jorcin (Eds.). Ecologia de reservatórios: impactos potenciais, ações de manejo e sistemas em cascata. São Carlos, Rima, 472p.

Cada, G. F., C. C. Coutant \& R. R. Whitney. 1997. Development of biological criteria for the design of advanced hydropower turbines. Idaho Falls, Idaho: U.S. Department of Energy, Idaho Operations Office. 85 p. DOE/ID-10578.

Carolsfeld, J., B. Harvey, C. Ross \& A. Baer. 2003. Migratory fishes of South America: biology, fisheries and conservation status. World Fisheries Trust, British Columbia, Canada. 380p.

Clay, C. H. 1995. Design of fishways and other fish facilities. Boca Raton, Lewis Publishers, 248p.

Fernandez, D. R., A. A. Agostinho \& L. M. Bini. 2004. Seletividade em uma escada de peixes experimental na barragem do reservatório de Itaipu. Brazilian Archives of Biology and Technology, 47(4): 579-586.

Freitas, C. E. C. \& M. Petrere Jr. 2001. Influence of artificial reefs on fish assemblage of the Barra Bonita Reservoir (São Paulo, Brazil). Lakes \& Reservoirs: Research and Management, 6(4): 273-278.

Godinho, H. P., A. L. Godinho, P. S. Formagio \& V. C. Torquato. 1991. Fish ladder efficiency in a southeastern Brazilian river. Ciência e Cultura, 43(1): 63-67.

Godoy, M. P. 1975. Peixes da sub-ordem Characoidei - Bacia do rio Mogi-Guaçu. Piracicaba, Franciscana.

Lowe-McConnell, R. H. 1999. Estudos ecológicos de comunidades de peixes tropicais. São Paulo, Edusp, 535p.

Luz-Agostinho, K. D. G., L. M. Bini, R. Fugi, A. A. Agostinho \& H. F. Júlio Jr. 2006. Food spectrum and tropic struture of the ichthyofauna of Corumbá Reservoir, Paraná River Basin, Brazil. Neotropical Ichthyology, 4(1): 61-68.

Makrakis, S., M. C. Makrakis, R. L. Wagner, J. H. P. Dias \& L. C. Gomes. 2007a. Utilization of the fish ladder at the Engenheiro Sergio Motta Dam, Brazil, by long distance migrating potamodromous species. Neotropical Ichthyology, 5(2): 197-204.

Makrakis, S., L. C. Gomes, M. C. Makrakis, D. R. Fernadez \& C. S. Pavanelli. 2007b. The Canal da Piracema at Itaipu Dam as a fishpass system. Neotropical Ichthyology, 5(2): 185-195.

Nakatani, K., A. A. Agostinho, G. Baumgartner, A. Bialetzki, P. V. Sanches, M. C. Makrakis \& C. S. Pavanelli. 2001. Ovos e larvas de peixes de água doce: desenvolvimento e manual de identificação. Maringá, EDUEM, 378p.

Okada, E. K., A. A. Agostinho \& L. C. Gomes. 2005. Spatial and temporal gradients in artisanal fisheries of a large Neotropical reservoir, the Itaipu Reservoir, Brazil. Canadian Journal of Fisheries and Aquatic Sciences, 62: 714-724.

Pagioro, T. A. \& S. M. Thomaz. 2002. Longitudinal patterns of sedimentation in a deep, monomictic subtropical reservoir (Itaipu, Brazil-Paraguay). Archiv fur Hydrobiologie, 154(3): 515-528.

Pereira, P. R., C. S. Agostinho, R. J. de Oliveira \& E. E. Marques. 2007. Trophic guilds of fishes in sandbank habitats of a Neotropical river. Neotropical Ichthyology, in press.

Petrere Jr., M. 1985. Migraciones de peces de agua dulce en America Latina: algunos comentarios. COPESCAL Documento Ocasional, Roma, 1:1-17.

Puth, L. M. \& K. A. Wilson. 2001. Boundaries and corridors as a continuum of ecological flow control: lessons from rivers and streams. Conservation Biology, 15(1): 21-30. 
Quirós, R. 1988. Structures assisting migrations of fish other than salmonids: Latin America. FAO-COPESCAL Technical Document, Rome, (5): 1-50.

Resende, E. K. 2003. Migratory fishes of the Paraguay Paraná Basin, excluding the Upper Paraná Basin. Pp. 99-156. In: Carolsfeld J., B. Harvey, C. Ross \& A. Baer (Eds.). Migratory Fishes of South America: biology, fisheries and conservation status. Victory, Canada, World Fisheries Trust, 380p.

Ruggles, C. P. 1980. A review of the downstream migration of Atlantic salmon. Halifax, Canadian Technical Report of Fisheries and Aquatic Sciences, 952p.

Taylor, B. W., A. S. Flecker \& R. O. Hall Jr. 2006. Loss of a harvested fish species disrupts carbon flow in a diverse tropical river. Science, 313:833-836.

Vazzoler, A. E. A. de M. 1996. Biologia da Reprodução de Peixes Teleósteos: Teoria e Prática. Maringá, EDUEM, 169p.

Received January 2007

Accepted June 2007 